\section{Commentary: Scapulocostal syndrome after trauma: A snap caused by a break}

\author{
Benny Weksler, MBA, MD
}

Scapulocostal syndrome, also known as "snapping scapula," is an under-recognized problem involving overhead or throwing motion of the upper extremities. ${ }^{1}$ It is often described as a snapping or grinding sensation accompanied with pain as the scapula touches the chest wall and an audible or palpable click near the anteromedial scapula. Pain can be elicited with movements that include shoulder abduction. The syndrome is more common in active young adults. Scapulocostal syndrome is often caused by bursitis but can also be caused by bony and soft-tissue abnormalities. $^{2}$ Treatment is usually nonoperative, with physical therapy and sometimes even massages, ${ }^{3}$ but when an anatomical abnormality is present, surgery is often indicated. ${ }^{4}$

In the present issue of the Journal, Nakamoto and colleagues ${ }^{5}$ present a patient with snapping scapula after thoracic trauma, caused by a sixth rib postfracture bone callous. The diagnosis was made by physical examination, but a 3-dimensional reconstruction of the chest wall clearly showed the area in which the scapula was rubbing the sixth rib bony callous. The authors resected the bone callous and reapproximated the rib with a titanium plate, solving the problem.

Scapulothoracic syndrome is relatively rare and often treated by orthopedic surgery. However, as demonstrated in this case report by Nakamoto and colleagues, thoracic

\footnotetext{
From the Division of Thoracic and Esophageal Surgery, Department of Thoracic and Cardiovascular Surgery, Allegheny General Hospital, Pittsburgh, Pa.

Disclosures: Proctor for Intuitive Surgery and speaker for AstraZeneca

The Journal policy requires editors and reviewers to disclose conflicts of interest and to decline handling or reviewing manuscripts for which they may have a conflict of interest. The editors and reviewers of this article have no conflicts of interest.

Received for publication June 2, 2020; revisions received June 2, 2020; accepted for publication June 6, 2020; available ahead of print June 14, 2020.

Address for reprints: Benny Weksler, MBA, MD, Division of Thoracic and Esophageal Surgery, Department of Thoracic and Cardiovascular Surgery, 320 E. North Ave, 14th Fl, South Tower, Pittsburgh, PA 15212 (E-mail: benny.weksler@ahn. org).

JTCVS Techniques 2020;3:380

2666-2507

Copyright (C) 2020 The Authors. Published by Elsevier Inc. on behalf of The American Association for Thoracic Surgery. This is an open access article under the CC BY-NCND license (http://creativecommons.org/licenses/by-nc-nd/4.0/).

https://doi.org/10.1016/j.xjtc.2020.06.003
}

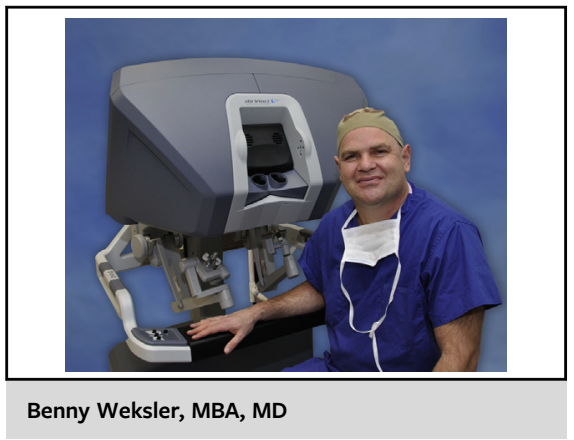

CENTRAL MESSAGE

Snapping scapula is often treated with conservative measures.

When anatomical abnormalities are present, surgical correction is indicated.

surgeons who take care of thoracic trauma and rib fractures should be aware of the pathophysiology of the "snapping scapula" and potential treatment options. Physical therapy should be the first line of treatment for most patients. However, when an apparent anatomical abnormality is diagnosed, such as a large bone callous, operative therapy should be considered and is often curative.

\section{References}

1. Russek AS. Diagnosis and treatment of scapulocostal syndrome. J Am Med Assoc. 1952;150:25-7.

2. Kuhne M, Boniquit N, Ghodadra N, Romeo AA, Provencher MT. The snapping scapula: diagnosis and treatment. Arthroscopy. 2009;25:1298-311.

3. Buttagat V, Eungpinichpong W, Chatchawan U, Arayawichanon P. Therapeutic effects of traditional Thai massage on pain, muscle tension and anxiety in patients with scapulocostal syndrome: a randomized single-blinded pilot study. J Bodyw Mov Ther. 2012;16:57-63.

4. Manske RC, Reiman MP, Stovak ML. Nonoperative and operative management of snapping scapula. Am J Sports Med. 2004;32:1554-65.

5. Nakamoto K, Sumiura S, Hashiyada H, Kiya S. Snapping scapula due to traumatic costal fractures: a case report. J Thorac Cardiovasc Surg Tech. 2020;3:375-7. 